\title{
The importance of turbulent kinetic energy on transport of juvenile clams (Mya arenaria)
}

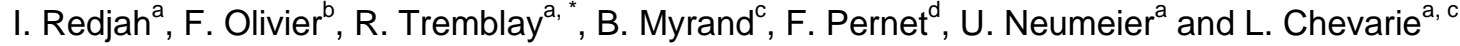 \\ a Institut des sciences de la mer (ISMER), Université du Québec à Rimouski, 310 Allée des Ursulines, Rimouski, \\ Québec, Canada G5L 3A1 \\ ${ }^{b}$ Muséum National d'Histoire Naturelle (MNHN), Département Milieux et Peuplements Aquatiques, UMR BOREA \\ 7208 CNRS/MNHN/P6/IRD, CRESCO, 38, rue du Port Blanc, 35800 Dinard, France \\ ${ }^{c}$ Centre maricole des îles-de-la-Madeleine (CeMIM), Ministère de l'Agriculture, des Pêcheries et de l'Alimentation \\ du Québec, 107-125, chemin du Parc, Cap-aux-Meules, Québec, Canada G4T 1B3 \\ d IFREMER, Laboratoire Environnement Ressources en Languedoc-Roussillon, Bd Jean Monnet, BP 171, 34203 \\ Sète, France \\ *: Corresponding author: R. Tremblay, Tel.: + 14187231986 \#1705; fax: + 1418724 1842, email address : \\ rejean tremblay@uqar.qc.ca
}

\begin{abstract}
:
Soft-shell clam, Mya arenaria, culture on the east coast of Canada is characterized by high loss following seeding. To evaluate the importance of passive transport due to currents, an experimental flume study was designed. The purpose was to measure the effects of hydrodynamic conditions, substrate, and clam size on dispersal in controlled laboratory condition and to interpret these results in relation to field measurements. Unidirectional currents with gradual increasing velocities ( 0 to $60 \mathrm{~cm} \mathrm{~s}^{-1}$ ) were applied to three substrates (muddy sand, medium sand, and coarse sand) in which clams from one of three size classes $(10,15$, and $20 \mathrm{~mm})$ had burrowed. We also examined the resulting effects of turbulent kinetic energy on the erosion of medium-grain sand and clams from the three size classes. Turbulent energy was created with a homemade device acting on the unidirectional currents. Nearly $95 \%$ of buried clams (all substrates and size classes together) were unaffected by unidirectional currents of up to $60 \mathrm{~cm} \mathrm{~s}^{-1}$, but only $10 \%$ withstood turbulent kinetic energy of $10.1 \mathrm{~J} \mathrm{~m}^{-3}$, a level that is lower than that measured in the field during an autumnal storm. The transport of clams was found to be directly related to substrate erosion-levels.
\end{abstract}

Keywords: Clam transport; Substratum erosion; Unidirectional currents; Turbulence; ADV; Flume 


\section{Introduction}

The soft-shell clam Mya arenaria, Linnaeus, 1758 is a burrowing suspension-feeding bivalve mollusc that is widely distributed over the North American coast. Clam fishing and culture is an important socio-economic activity in many small communities; however, as is the case along the US East coast, the biomass has generally declined, mainly as a result of overfishing, environmental degradation and diseases (Arnold et al., 2002; Beal and Vencile, 2001; McGladdery et al., 2001). In Canada, mollusc culture is an important industry, and the soft-shell clam is considered as an important species for diversification purposes (Anonymous, 2009).

Very little is known about the cultivation of soft-shell clams in eastern Canada as it is relatively new and is still mostly at a R\&D level (Calderon, 2007). These clams reach commercial size four to five years after seeding (Beal, 2005). During this period, they are subjected to losses mainly attributable to diseases, like haemic neoplasia, predation and passive transport due to currents (Beal, 2006a, b; Beal and Kraus, 2002; Bourque et al., 2002; Hunt, 2004b; McGladdery et al., 2001; Miron et al., 2005). In lagoons of the Îles-de-laMadeleine (southern Gulf of St. Lawrence, eastern Canada), sometimes less than $30 \%$ of clams seeded during summer at $15 \mathrm{~mm}$ shell-length (SL) are retrieved the following spring (Chevarie et al., 2006). We suggest that mechanisms associated with clam losses will be related to predation and/or passive transport. In eastern Canada, only the population of $M$. arenaria from Prince Edward Island was unequivocally affected by haemic neoplasia (Delaporte et al., 2008) that was reported to cause massive mortality (McGladdery et al., 2001). In Îles-de-la-Madeleine lagoons, a neoplasia diagnosed by hematocytology showed that clams were only slightly affected (Delaporte et al., 2008). Indeed, a five-year histopathological survey showed that this disease did not cause the losses observed during the first autumn and winter following seeding among clams in the îles-de-la-Madeleine (Réjean Tremblay, personal observation).

Survival of juvenile clams is correlated with the burrowing depth of individuals, which is also linked with SL (Zaklan and Ydenberg, 1997). Larger individuals burrow deeper than smaller ones (Zaklan and Ydenberg, 1997). Since small clams are nearer the sediment surface, they are susceptible to transport by substrate erosion at the same shear velocities as inert particles (Matthiessen, 1960; Roegner et al., 1995; St-Onge and Miron, 2007; St-Onge et al., 2007). Mya arenaria lives in sediments with a large range of grain sizes (LeBlanc and Miron, 2006; Roegner et al., 1995). Relationships between shear velocity, sediment grain size and SL length on sediment erosion and transport of juvenile clams have been established at shear velocities as low as $1.6 \mathrm{~cm} \mathrm{~s}^{-1}$ (Hunt, 2004b). Turbulence (measured as turbulent kinetic energy, TKE) are major factors influencing bedload erosion and could have a strong influence on clam transport (Hendriks et al., 2006; Pope et al., 2006). Therefore, experiments manipulating TKE are likely more representative of conditions encountered by soft-shell clams in the wild than those investigating only the effect of unidirectional current velocities.

Our study was designed to determine the effect of unidirectional current and combined current-waves on clam transport as a function of SL and sediment type. Our main hypothesis is that TKE has a higher impact on clam transport than shear velocity. Because critical shear velocity $\left(u^{*}{ }_{c}\right)$ increases with increasing grain-size and/or sediment cohesiveness (Sobral and Widdows, 2000), we predicted that clam transport varies according to sediment type.

\section{Material and methods}

\subsection{Aquatron flume description}

Experiments were carried out in a racetrack recirculating flume (Aquatron) at the Aquaculture Station of ISMER in Pointe-au-Père (Rimouski, Qc, Canada). The Aquatron flume (Fig. 1) is 
a smaller version of the HYCOBENTHOS flume located in the Marine Station of Dinard, France (Muséum National d'Histoire Naturelle, MNHN) (Jonsson et al., 2006; Olivier, 1997). The main differences concern the flume dimensions (total length $=4.3 \mathrm{~m}$, channel width $=$ $0.45 \mathrm{~m}$ ), the experimental section characteristics (length $=0.91 \mathrm{~m}$, depth $=0.15 \mathrm{~m}$ ), and the flow induction device (12 PVC disks [0.5 m diameter] connected via a pulley system to a direct-power $1 \mathrm{hp}$ variable-speed motor). Flow through the flume channel is driven by the friction of the rotating disks; these disks are immersed in the seawater and their speed is set by digital command. When needed, a wave-current benthic boundary layer (BBL) can be produced using a wave generator located at the beginning of the straight flume section: an immersed triangular piece of wood moves up and down at a fixed frequency to create waves.

\subsection{Aquatron flow characterization}

The flume was filled to a depth of $15 \mathrm{~cm}$ with $10-\mu \mathrm{m}$-filtered natural seawater (salinity $=28.5$ $\pm 0.2)$ at room temperature $\left(20.2 \pm 0.4^{\circ} \mathrm{C}\right)$. Flow measurements were acquired with a 3-axis $16 \mathrm{MHz}$ SonTek MicroADV (San Diego, USA; Acoustic Doppler Velocimeter) at a data rate of $25 \mathrm{~Hz}$, and 7500 data points were averaged for each height. For each flow profile, velocities were measured at 13 heights between 0.5 and $9.0 \mathrm{~cm}$ above the bottom, and shear velocity $\left(u_{*}\right)$ was computed from the vertical velocity profile in the logarithmic layer according to the "law of the wall" using the Kármán-Prandtl equation (Bergeron and Abrahams, 1992). To maximize the BBL development, a $5 \mathrm{~mm}$ thick PVC sand-coated plate was fixed on the flume bed in the whole straight section.

The relationship between shear velocity and velocity at $5 \mathrm{~cm}$ above bottom $\left(U_{5 \mathrm{~cm}}\right)$ was explored to simplify measurement during following erosion experiments. Nine flow profiles for velocities of $U_{5 \mathrm{~cm}}$ between 2 and $50 \mathrm{~cm} \mathrm{~s}^{-1}$ were measured and their shear velocity computed. A linear regression gave following relationship between $U_{5 \mathrm{~cm}}$ and shear velocity:

$\mathrm{u}_{*}=0.0338 \times \mathrm{U}_{5 \mathrm{~cm}}+0.0251 \quad\left(\mathrm{R}^{2}=0.949\right)$

This equation was used subsequently to convert $U_{5 \mathrm{~cm}}$ for each flow speed treatment to shear velocity $u_{*}$.

To determine potential longitudinal and transversal velocity gradients in the experimental section, we measured $U_{5 \mathrm{~cm}}$ along three transects across the channel ( $A, B$ and $C$ ) of eight regularly distributed points (intervals of $5.1 \mathrm{~cm}$; Fig. 1) for a free stream velocity of $15 \mathrm{~cm} \mathrm{~s}^{-1}$. Transects were positioned $15 \mathrm{~cm}$ after the start (C), at the center (B), and $15 \mathrm{~cm}$ before the end $(A)$ of the experimental area. For current-wave experiments, the mean turbulent kinetic energy $\left(T K E, \mathrm{~J} \mathrm{~m}^{-3} ; \mathrm{N}=5\right.$ ) levels were acquired along the $B$ transect using the MicroADV at $a$ data rate of $25 \mathrm{~Hz}$, with 1500 data points per measurement $\left(T=15.6 \pm 0.5^{\circ} \mathrm{C}\right.$; salinity $=27.6$ $\pm 0.6)$. TKE was then calculated using the following formula (Pope et al., 2006):

$$
\text { TKE }=1 / 2 \rho\left(\mathbf{u}^{\prime 2}{ }_{\text {mean }}+\mathbf{v}^{\prime 2}{ }_{\text {mean }}+\mathbf{w}^{\prime 2}{ }_{\text {mean }}\right)
$$

where $\rho$ is the water density $\left(\mathrm{kg} \mathrm{m}^{-3}\right)$ and $\mathrm{u}^{\prime}, \mathrm{v}^{\prime}, \mathrm{w}^{\prime}$ are the turbulent components of flow velocity $\left(\mathrm{m} \mathrm{s}^{-1}\right)$ on $x, y$ and $z$ axis respectively.

When sediment was introduced into the experimental section (see below), we included rugosity parameters to calculate shear stress $\left(u_{*}\right)$ from the $U_{5 \mathrm{~cm}}$ measurements using the Kármán-Prandtl formula:

$$
\begin{array}{lllllll}
u_{*} & = & \times & U_{z} & I & \ln \left(z / z_{0}\right)
\end{array}
$$

where $\kappa$ is the Karman constant $(\kappa=0.4), z=5 \mathrm{~cm}, z_{0}=k_{s} / 30, k_{s}=2.5 D_{50}$, and $D_{50}$ is the median grain size diameter of the sediment, varying from 0.3 to $0.44 \mathrm{~cm}$. 


\subsection{Unidirectional current experiments}

The three different substrates with distinct mean grain sizes used for this set of flume experiments originated from the Îles-de-la-Madeleine clam seeding site $\left(47^{\circ} 26^{\prime} \mathrm{N} 61^{\circ} 50^{\prime} \mathrm{W}\right.$;

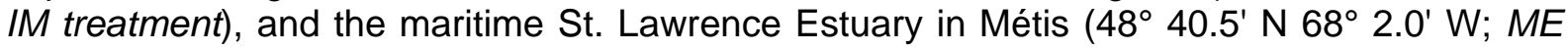
treatment) and Pointe Pouliot near Rimouski (48 $29.4^{\prime} \mathrm{N} 68^{\circ} 29.6^{\prime} \mathrm{W}$; PP treatment). These intertidal sediments were not sieved and only very large objects were removed before filling the recess of the flume.

Two surficial sediment samples were collected before and after each experiment to measure particle size. Samples for grain size determinations were homogenized, sieved, and dried at $60^{\circ} \mathrm{C}$ to determine percentage weights of different fractions using a sieve column with a ratio of successive mesh sizes of $2^{0.25}$ (McManus, 1988). Grain-size values were determined by the geometric method of moments using the Gradistat program (Blott and Pye, 2001).

Before each experiment involving clams, we assessed the shear stress ranges in the experimental section for each substratum by measuring $U_{5 \mathrm{~cm}}$ on transects $A, B$, and $C$ (Fig. 1). Values of $u_{*}$ corresponding to $U_{5 \mathrm{~cm}}$ equal to $15,30,45$ and $60 \mathrm{~cm} \mathrm{~s}^{-1}$ were also calculated from equation (2). All substrates were kept in a $5^{\circ} \mathrm{C}$ controlled temperature room during the experiments until their use.

Juveniles were collected, in early November 2006, from HAM lagoon by sieving sediment on a $5 \mathrm{~mm}$ mesh. Clams were sent directly on sea ice to the Station Aquicole de Pointe-au-Père, which is associated to Institut des Sciences de la Mer de Rimouski. Prior to experiments, 600 clams (shell lengths between 5 and $30 \mathrm{~mm}$ ) were maintained for one month before experiment in 200 I tanks filled with $12 \mathrm{~cm}$ deep ME-like sediment and $10 \mu \mathrm{m}$ filtered natural seawater at constant temperature $\left(16.7 \pm 0.8^{\circ} \mathrm{C}\right)$ and salinity $(26.0 \pm 0.7)$. They were fed with a standard hatchery diet consisting of equal proportions of the microalgae Pavlova lutheri, Isochrysis aff. Galbana and Nannochloropsis sp. The diet was supplied continuously to maintain a total concentration of $\sim 30$ cells $\mu^{-1}$ in the tanks, allowing clams to be fed to satiety.

Clams were sorted into three size classes based on their shell length (SL): $10.8 \pm 1.0$, $15.6 \pm 1.0$, and $19.8 \pm 1.1 \mathrm{~mm}$ (here after referred to as 10,15 and $20 \mathrm{~mm} \mathrm{SL}$ ). For each trial, the experimental section was filled with a randomly chosen substrate and the flume was then filled with $10 \mu \mathrm{m}$ filtered seawater $\left(T=16.7 \pm 0.8^{\circ} \mathrm{C}\right.$; salinity $\left.=26.0 \pm 0.7\right)$ to a height of $15 \mathrm{~cm}$. Ten juvenile clams from one size class, also selected randomly, were placed on the sediment surface in the middle of the experimental area (B transect, Fig. 1). The clams were placed in parallel and separated by $5 \mathrm{~cm}$ from each other so that they were all facing the incoming flow. A unidirectional current of $10 \mathrm{~cm} \mathrm{~s}^{-1}\left(\mathrm{U}_{5 \mathrm{~cm}}\right)$ was applied for $16 \mathrm{~h}$ to induce individuals to burrow into the substrate: this velocity was found to significantly increase both the mean proportion of juvenile clams to burrow (St-Onge and Miron, 2007) and the burial rate (St-Onge and Miron, pers. com.). At the start of the experiment, the clams' burial state (buried or not) was noted and the current velocity was then increased with a maximal acceleration of $1 \mathrm{~cm} \mathrm{~s}^{-1} \mathrm{~min}^{-1}$ to avoid burst effects. Only clams that were initially completely buried with visible siphon in or out of the sediment were considered in the data analysis. Nine increasing flow regimes were applied over 30 minutes each, corresponding to free stream velocities $\left(\mathrm{U}_{\infty}\right)$ equal to $20,25,30,35,40,45,50,55$, and $60 \mathrm{~cm} \mathrm{~s}^{-1}$; clam positions were noted at the beginning and at the end of each flow step. At the end of each test, the flume was completely cleaned and washed before the next trial. Five replicates $(n=5)$ for each treatment (sediment $\times \mathrm{SL}$ ) were run $(\mathrm{N}=45)$ at a rate of one treatment per day. Each day, combination of treatment (sediment $\times \mathrm{SL}$ ) was selected randomly.

\subsection{Turbulence experiments}

The experimental protocol adopted for this set of experiments was similar to the previous one except for i) the water depth, which was increased to $21 \mathrm{~cm}$, and ii) the flow 
regimes applied to the buried clams, which lasted 30 minutes, corresponded to $U_{\infty}$ equal to $20,40,45,50$ and $55 \mathrm{~cm} \mathrm{~s}^{-1}$, and integrated a constant turbulent energy produced by 120 cycles per minute (CPM) of the wave generator. A five-minute stabilization period was applied after each flow increase to allow the observation of clam positions. Temperature and salinity remained stable during the whole set of experiments $\left(17.5 \pm 0.3^{\circ} \mathrm{C}\right.$ and $24.5 \pm 0.5$, respectively).

\subsection{Field measurements}

To characterize the hydrodynamic regime in the field, an $6 \mathrm{MHz}$ Vector velocimeter, (Nortek, Rud, Norway) was deployed from 5 to 13 October 2006 near the main clam seeding site $\left(47^{\circ}\right.$

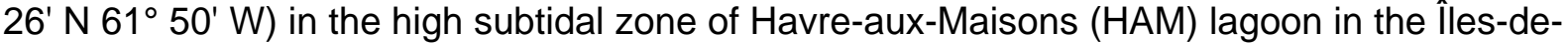
la-Madeleine (southern Gulf of St. Lawrence, eastern Canada). The velocimeter sensor was located $27.7 \mathrm{~cm}$ above the sediment surface and was sampling at $8 \mathrm{~Hz}$ for $6.83 \mathrm{~min}$ (3280 data points) every $15 \mathrm{~min}$. The sampling volume of the velocimeter is positioned $15.7 \mathrm{~cm}$ from the sensor; it was therefore located $12 \mathrm{~cm}$ above sediment level to avoid interference due to sand accumulation.

On the same site, bed elevation change was measured twice a week from 18 September to 28 November 2007 using nine horizontal rods initially anchored $30 \mathrm{~cm}$ above the sediment level and scattered over a total area of $110 \mathrm{~m}^{2}$. The first data recorded were considered as controls and further positive or negative values correspond to sediment deposition or erosion, respectively.

\subsection{Data analysis}

Field data from the ADV were filtered to remove low tide and aberrant data. Maps of the shear velocities in the flume were produced using the linear interpolation gridding method in Surfer software (ver. 7.0). Two-way ANOVAs were performed on mean shear stress data to assess $i)$ the transversal (four treatments from the internal to the external side of the flume) and longitudinal (three treatments from the beginning to the end of the experimental section) gradients (7126 data points per treatment) and ii) their relationship with both free stream velocity (four treatments) and sediment type (three treatments) corresponding to 24 data points per treatment (measurement grid in Fig. 1).

Three-way split plot ANOVAs were performed on the unidirectional current experiment data to determine differences in the clam transport rate as a function of substrate type, clam size and free stream velocities. The units of replication were the five runs performed for each of the nine substrate type $\times$ clam size treatments; the main plots were substrate (MI, ME and PP) and clam size classes (10, 15 and $25 \mathrm{~mm}$ ), and sub-plots were free stream velocities (10 values from 10 to $60 \mathrm{~cm} \mathrm{~s}^{-1}$ ). Two-way split plot ANOVAs were performed on data from the turbulent kinetic energy experiments, with size classes as the main plot and TKE (four levels from 0 to $10.1 \mathrm{~J} \mathrm{~m}^{-3}$ ) as subplots. These setups of effect of flow velocity include cumulative effect of increasing flow, even if a stabilization period have been applied between each flow increase. Thus, we consider flow velocity as a subplot factor with limiting interpretation, as the losses of clams could be influenced by earlier velocity. Advantage of this setup is the realization of each flow velocity measure in the same day and limit temporal variability of measures inherent to use of one flume.

For all these analysis, normality and homogeneity of variance was directly checked by observations of residuals; (Log+1) transformations were applied when required. When needed, LSD post-hoc comparisons tests were performed to identify groups differing from the others. Data in text, table and figures are presented with mean \pm SD. 


\section{Results}

\subsection{Aquatron flow characterization}

In general, vertical velocity profiles were fully developed and the regression coefficients related to $u_{*}$ calculated using the "law of the wall" method were always above 0.96 (see examples in Fig. 2). In the experimental area, the shear stress velocities associated with a 15 $\mathrm{cm} \mathrm{s}^{-1}$ free stream velocity varied according to the longitudinal and transversal gradients (significant longitudinal $\times$ transversal interaction, $d f=6, M S=0.04, F=288.9, p<0.001$; Fig. 3). Post-hoc comparisons show significant differences between all treatments $(p<0.001)$, with minimum mean shear stresses found on the internal side of the flume, especially at the beginning of the experimental section (mean $\mathrm{u}_{*}=0.679 \mathrm{~cm} \mathrm{~s}^{-1}$ ). Maximum shear stress values were observed in the inner side of the experimental area, particularly at the end of the experimental area (mean $\mathrm{u}_{*}=0.750 \mathrm{~cm} \mathrm{~s}^{-1}$, Fig. 3). The gradient between the external and the internal sides is related to the gradual increase in the benthic boundary layer from the leading edge, which is characteristic of flume flows (Muschenheim et al., 1986; Nowell and Jumars, 1984), as well as to the lateral gradient associated with the flume walls. However, in the experimental section of the Aquatron flume, the spatial variability of the shear stress is low for a mean $U_{\infty}$ of $15 \mathrm{~cm} \mathrm{~s}^{-1}$, always less than $10 \%$ (in the experimental section: $u_{*}=0.72$ $\pm 0.03 \mathrm{~cm} \mathrm{~s}^{-1}$ ).

In the unidirectional current experiments, mean shear stresses were related to both mean $\mathrm{U}_{5 \mathrm{~cm}}$ and substrate type (significant interaction, $\mathrm{df}=6, \mathrm{MS}=0.032, \mathrm{~F}=3.447, \mathrm{p}=0.0027$ ). For a given $U_{5 \mathrm{~cm}}$, the mean $u_{*}$ was generally similar for the three sediments but was lowest for the IM-15 $\mathrm{cm} \mathrm{s}^{-1}$ treatment. When the coarser ME substrate was exposed to high flow regimes, stronger mean shear stresses were generated (Table 1). In general, the BBL flow regime was always turbulent $(\operatorname{Re}>9000)$; it was most frequently characterized by a transitory rugosity on the experimental section $\left(3.5<\mathrm{Re}^{\star}<49\right)$, but also rarely showed a smooth flow (for $U_{5 \mathrm{~cm}}=15 \mathrm{~cm} \mathrm{~s}^{-1}$ on IM and ME sediments). In these flow conditions, TKE was very low (between 0.07 to $1.78 \mathrm{~J} \mathrm{~m}^{-3}$ ) with the lowest values measured above PP sediment.

In turbulence experiments, TKE was positively related to increasing $U_{5 \mathrm{~cm}}$ (Fig. 4), with maximum values $\left(10.71 \mathrm{~J} \mathrm{~m}^{-3}\right)$ obtained for $\mathrm{U}_{5 \mathrm{~cm}}=55 \mathrm{~cm} \mathrm{~s}^{-1}$. This maximum was slightly below the mean TKE values measured in the field $\left(\sim 12 \mathrm{~J} \mathrm{~m}^{-3}\right.$; see below).

\subsection{Flume experiments}

Grain sizes of the three sediments are presented in Fig. 5. The samples comprised 1) a clean well-sorted medium sand with a mean grain size of $0.297 \mathrm{~mm}$ (IM), 2) a clean well sorted slightly gravelly to gravelly sand with a mean grain size of $0.421 \mathrm{~mm}(\mathrm{ME})$, and 3) a heterogeneous muddy gravelly sand with a mean grain size of $0.332 \mathrm{~mm}(\mathrm{PP})$.

At the beginning of the unidirectional current experiments $(n=5)$, the percentage of buried clams was always higher than $82 \%$. We found only a significant size effect ( $d f=2$, MS $=0.38$, $\mathrm{F}=3.62, \mathrm{p}=0.047$ ). Post-hoc LSD tests showed a weak significant decrease of the mean burial proportion of $15 \mathrm{~mm}$ SL clams $(p<0.05)$. In fact, we observed that $15 \mathrm{~mm}$ SL clams were dislodged slightly more in the IM treatment (10\%) than the others sediment treatment (Fig. 6). For the other trials, we were unable to dislodge the clams even at the highest flow regime (for the ME-60 $\mathrm{cm} \mathrm{s}^{-1}$ treatment, mean $\mathrm{u}_{*}=2.10 \mathrm{~cm} \mathrm{~s}^{-1} \pm 0.07 \mathrm{~cm} \mathrm{~s}^{-1} \mathrm{SE}$ ).

The percentage of all size classes of buried clams was significantly affected by the wavecurrent flow regime $(\mathrm{df}=1, \mathrm{MS}=4.48, \mathrm{~F}=85.9, \mathrm{p}<0.001)$, with lower values corresponding to the most dynamic regime (LSD tests, $p<0.001$; TKE $=10.1 \mathrm{~J} \mathrm{~m}^{-3}$ ). In fact, more than $80 \%$ of juvenile clams were dislodged when TKE reached $10.1 \mathrm{~J} \mathrm{~m}^{-3}$ (Fig. 7). However, lower percentages of the 15 and the $20 \mathrm{~mm}$ clams were buried at the beginning of the experiment (70\% and $60 \%$, respectively) than the smaller individuals (100\%). 


\subsection{Field measurements}

Wind, mean current speed and turbulent kinetic energy (TKE) measured in October 2006 at the HAM field site are shown in Fig. 8. Very high TKE values were observed when winds and currents were high $\left(15 \mathrm{~J} \mathrm{~m}^{-3}\right.$ on 5 October, and up to $20 \mathrm{~J} \mathrm{~m}^{-3}$ on 13 October; mean TKE $=12$ $\mathrm{J} \mathrm{m}^{-3}$ ), corresponding to stormy conditions. The average temperature measured by the velocimeter was $14.1 \pm 3.18^{\circ} \mathrm{C}$. In the field, instantaneous currents, generally co-occurring with windy conditions (wind velocities temporarily reaching $15 \mathrm{~m} \mathrm{~s}^{-1}$ ), were always below 24 $\mathrm{cm} \mathrm{s}^{-1}$; this velocity would correspond to a maximum shear stress induced by currents of only $1.16 \mathrm{~cm} \mathrm{~s}^{-1}$. Bed elevation measurements showed several erosion and deposition periods (Fig. 9). Stormy conditions generate sediment erosion during two main periods: between 2 and 18 October $(\Delta z=-1.6 \mathrm{~cm})$ and between 26 October and 5 November $(\Delta z=-2.0 \mathrm{~cm})$. Sediment deposition was observed between these periods at rates of 0.1 to $0.2 \mathrm{~cm} \mathrm{~d}^{-1}$.

\section{Discussion}

\subsection{Effect of unidirectional currents}

We were mostly unable to erode juvenile $(10-20 \mathrm{~mm})$ Mya arenaria in our flume, even with shear velocities reaching $2.10 \mathrm{~cm} \mathrm{~s}-1$ (= unidirectional flow of $60 \mathrm{~cm} \mathrm{~s}$ s$^{-1}$ ) Only $15 \mathrm{~mm} \mathrm{SL}$ clams were slightly eroded in the medium sand treatment at $u_{*_{\mathrm{C}}}>1.5 \mathrm{~cm} \mathrm{~s}^{-1}$ (= unidirectional flow $>45 \mathrm{~cm} \mathrm{~s}^{-1}$ ), corresponding to the erosion of the top few millimetres of sediment. Our data are in accordance with most of the flume studies focusing on the bedload transport of small juvenile clams (SL < 8 mm) (Gulmann et al., 2001; Hunt, 2004b, 2005; Jennings and Hunt, 2009; Roegner et al., 1995): the transport rate of small juvenile $M$. arenaria increases with increasing shear velocity and sediment fluxes. In our study, we used 1- to 2-year-old juveniles ( $\mathrm{SL}>8 \mathrm{~mm}$ ), which are typically the age seeded by shellfish farmers in the îles-dela-Madeleine. Hunt (2004b) showed that the transport rate of $4.9 \mathrm{~mm} \mathrm{SL} \mathrm{M}$. arenaria was negligible, and she suggested that these juveniles had reached a refuge size where they were not subjected to erosion by shear velocities $<1.6 \mathrm{~cm} \mathrm{~s}^{-1}$. Our unidirectional flume studies confirm this hypothesis. By contrast, St-Onge and Miron (2007) observed high clam dislodgment rates (up to 50\%) for larger juvenile clams (10 mm $<\mathrm{SL}<20 \mathrm{~mm}$ ), corresponding to a clean sand, heavy bedload transport for free stream velocities above 29 $\mathrm{cm} \mathrm{s}^{-1}\left(\mathrm{u}_{*}=2.01 \mathrm{~cm} \mathrm{~s}^{-1}\right)$ applied for one hour. The mean shear velocity in our study was 2.1 $\mathrm{cm} \mathrm{s}^{-1}$ while each trial lasted more than 5 hours, and no bulk sediment transport was observed for any of the sediments used. Further, the clams in their study were buried manually just below the surface at the onset of the experiment while those in the present study were allowed to bury by themselves for about $16 \mathrm{~h}$. Such differing results may also be due to differences in the BBL flume flows, since St-Onge and Miron (2007) used a small flume (straight channel length $=0.75 \mathrm{~m}$, width $=0.2 \mathrm{~m}$ ), which does not allow good BBL flow development and may be affected by strong lateral velocity gradients and high turbulence levels (Muschenheim et al., 1986; Vogel, 1994). The Aquatron flume produces a welldeveloped BBL with low lateral gradients (less than 10\% in our trials), characteristics that are typical of recirculating flumes (Jonsson et al., 2006). In our experiment, although sediment erosion occurred for shear stresses above $1.5 \mathrm{~cm} \mathrm{~s}^{-1}$ (= unidirectional flow $>45 \mathrm{~cm} \mathrm{~s}^{-1}$ ) and was highest on the clean medium sand treatment, no clam dislodgment was observed. Such results imply active burrowing by clams to reduce or avoid transport, as suggested by Roegner et al. (1995) and Lundquist et al. (2004a). Burrowing behaviour and burial depth varies according to water temperature, sediment type, clam size, shear velocities, and algal mats (Auffrey et al., 2004; Lundquist et al., 2004a; Pariseau et al., 2007; St-Onge et al., 2007; Zaklan and Ydenberg, 1997). With the exception of the high shear velocities and the size classes tested, our experimental conditions were favourable for burrowing, i.e., water temperature of $18^{\circ} \mathrm{C}$, mean grain diameter $<500 \mu \mathrm{m}$, no algal mats. In the absence of 
turbulence, we can conclude that juvenile clams (SL $>8 \mathrm{~mm}$ ) are large enough not to be eroded by shear velocities exceeding $2 \mathrm{~cm} \mathrm{~s}^{-1}$.

\subsection{Effect of turbulence}

Our turbulence experiments revealed that juveniles with a mean shell length as large as 20 $\mathrm{mm}$ are still subject to displacement when they are submitted to high interacting wavecurrent flows. For TKE exceeding $10 \mathrm{~J} \mathrm{~m}^{-3}$, the transport rate of clams was above $80 \%$ for all the tested size classes, and this was mainly caused by the bulk transport of the sediment. In laboratory studies, Roegner et al. (1995) and Hunt (2005) clearly showed the positive relationship between sediment and clam transport at high flow speeds through bedload transport. Several studies (Hunt, 2005; Hunt et al., 2007; Hunt and Mullineaux, 2002) have confirmed these results on soft-shell clam recruits in the highly stratified Navesink estuary, where turbulence is dampened by pycnoclines (Fugate and Chant, 2005), as have other field studies conducted on different clam species on tidal flats (Beukema and Devlas, 1989; Norkko et al., 2001) or in subtidal habitats (Olivier et al., 1996; Olivier and Retiere, 1998). The effect of turbulence through wind stress and associated waves has been observed in the field on the post-larvae and juveniles of many invertebrate species (Olivier et al., 1996), including bivalves (Emerson, 1991; Lundquist et al., 2006). Concerning Mya arenaria juveniles, Emerson (1991) and Emerson and Grant (1991) have clearly demonstrated, using sediment traps, that bivalve dispersal was correlated to wind-driven sediment transport, especially when wind speeds exceed 5-7 $\mathrm{m} \mathrm{s}^{-1}$. In their experiments, bedload transport of juveniles (mean = $9 \mathrm{~mm} \mathrm{SL}$; up to $28 \mathrm{~mm}$ ) was important, with maximum values in the traps of 2000 ind. $\mathrm{m}^{-1} \mathrm{~d}^{-1}$. In the Îles-de-la-Madeleine, periods of high turbulence corresponding to autumn storms could induce bedload transport of seeded clam juveniles. We measured TKE exceeded $10 \mathrm{~J} \mathrm{~m}^{-3}$ (up to $20 \mathrm{~J} \mathrm{~m}^{-3}$ ) in field conditions and demonstrated that this was a threshold value for eroding both sediment and seeded clams.

\subsection{Expected distance of dispersal}

Some recent studies have focused on the expected spatial scales for bedload transport through field or modelling experiments. Hydrodynamic models predict that the average distance travelled by bedload-dispersing organisms in shallow estuaries is on the order of $100 \mathrm{~m} \mathrm{~d}^{-1}$ (Lundquist et al., 2004b). Field observations by Lundquist et al. (2006) revealed that rates of passive bedload transport, as well as resuspension higher into the water column, increased with wave activity, suggesting that storm-related transport is an important process for long-distance recolonization. Norkko et al. (2001) measured the dispersal distances of Maconoma liliana juveniles in the field and calculated that individuals could travel over several metres within a tidal cycle on an intertidal sandflat. On the same species, Petuha et al. (2006) estimated that bedload transport of juveniles could account for a dispersal distance of $80 \mathrm{~m}$ on a spring tide. For Mya arenaria juveniles, recent work by Jennings and Hunt (2009) assessed bedload dispersal rates of 2 to $40 \mathrm{~cm} \mathrm{~h}^{-1}$ for small individuals $(\mathrm{SL}<1.5 \mathrm{~mm})$ in relatively high flume flows $\left(1.13<\mathrm{u}_{*}<1.30 \mathrm{~cm} \mathrm{~s}^{-1}\right)$ and of $10 \mathrm{~cm}$ $\mathrm{h}^{-1}$ in the field. Based on results from a 1D numerical bedload transport model of juvenile clams by tidal currents, including $M$. arenaria recruits, Hunt et al. (2009) concluded that dispersal distances could reach several kilometres in one month $\left(100 \mathrm{~m} \mathrm{~d}^{-1}\right)$ and would be responsible for modifying patterns of distribution and abundance. Such processes could explain in part the high recruitment variability observed for soft-shell clams in the field at scales of metres to kilometres (Bowen and Hunt, 2009; Emerson and Grant, 1991; Hunt et al., 2003; LeBlanc and Miron, 2006). In HAM lagoon, residual tidal currents rapidly decrease away from the inlets, with residual flows almost vanishing near the shellfish farming concessions (Guyondet and Koutitonsky, 2008). According to Koutitonsky and Tita (2006), wind events during storms would probably alter this residual circulation, but their influence 
would be limited to a few tidal cycles. In HAM lagoon, strong local winds are predominantly blowing from the western sector (Drapeau, 1988), and we should thus expect bedload transport of juveniles from the tidal flats to the deeper parts of the lagoon, which would contribute to a loss of stock for shellfish farmers.

\subsection{Other potential causes of juvenile Mya loss}

The loss of juvenile clams during autumn could be attributed to post-settlement processes such as predation (Beal and Kraus, 2002; Hunt et al., 2003; Hunt and Mullineaux, 2002). In HAM lagoon, potential predators are the rock crab Cancer irroratus, the green crab Carcinus maenas (newly arrived in the Îles-de-la-Madeleine) and the nemertean Cerebratulus lacteus, which could drastically affect populations of soft-shell clam adults and juveniles (Bourque et al., 2002; Miron et al., 2005). The risk of predation by epibenthic crabs generally decreases with increasing size/age (Sousa, 1993). However, Miron et al. (2005) showed that the native rock crab is a potential threat for commercial bivalves, particularly juveniles ( $\mathrm{SL}<25 \mathrm{~mm}$ ).

Predator foraging may increase sediment erosion and thus displace juveniles (Hunt, 2004a) by decreasing the $\mathrm{u}_{*_{c}}$ for bedload transport. More generally, bedload transport of both sediment and juveniles depends on a variety of biological factors that modify critical shear velocities to erode the substratum, including stabilization or destabilization due to infauna (Olivier et al., 1996; Volkenborn et al., 2009; Widdows and Brinsley, 2002)

\section{Conclusion}

Our flume studies have clearly shown that high levels of turbulence could explain the loss of commercial juvenile soft-shell clams in the îles-de-la-Madeleine by wind generated waves during storms. We now have to quantify these processes in the field using bedload traps to assess scales of dispersal and turnover of the seeded population, and to test the hypothesis of predation by rock crabs, green crabs, and nemerteans, which were rejected until now to explain high losses of seed.

\section{Acknowledegments}

We thank Sylvain Leblanc and Gilles Desmeules from ISMER for their field support and for providing and analyzing the environmental data. Special tanks to Laurie Devine for the linguistic revision. We are grateful to the Réseau Aquaculture Québec (RAQ) for their financial support; this study was also partially supported by an NSERC Discovery Grant to Drs R. Tremblay and F. Pernet.

\section{References}

Anonymous. 2009. Aquaculture Innovation and Market Access Program (AIMAP), Department of Fisheries and Oceans Canada. http://www.dfompo.gc.ca/aquaculture/sustainable-durable/AIMAP-PIAAM-2009-10-application-info-eng.rtf, consulted October $7^{\text {th }}, 2009$ ).

Arnold, W. S., D. C. Marelli, M. Parker, P. Hoffman, M. Frischer and J. Scarpa (2002). "Enhancing hard clam (Mercenaria spp.) population density in the Indian River Lagoon, Florida: A comparison of strategies to maintain the commercial fishery." J. Shellfish Res. 21(2): 659-672. 
Auffrey, L. M., S. M. C. Robinson and M. A. Barbeau (2004). "Effect of green macroalgal mats on burial depth of soft-shelled clams Mya arenaria." Mar. Ecol. Progr. Ser. 278: 193203.

Beal, B.F. (2005). Soft-shell clam, Mya arenaria, mariculture in Maine, USA : Opportunities and challenges. AAC Spec. Publ. No. $9: 41-44$.

Beal, B. F. (2006a). "Biotic and abiotic factors influencing growth and survival of wild and cultured individuals of the softshell clam (Mya arenaria L.) in eastern Maine." J. Shellfish Res. 25(2): 461-474.

Beal, B. F. (2006b). "Relative importance of predation and intraspecific competition in regulating growth and survival of juveniles of the soft-shell clam, Mya arenaria L., at several spatial scales." J. Exp. Mar. Biol. Ecol. 336(1): 1-17.

Beal, B. F. and M. G. Kraus (2002). "Interactive effects of initial size, stocking density, and type of predator deterrent netting on survival and growth of cultured juveniles of the soft-shell clam, Mya arenaria L., in eastern Maine." Aquaculture 208(1-2): 81-111.

Beal, B. F. and K. W. Vencile (2001). "Short-term effects of commercial clam (Mya arenaria L.) and worm (Glycera dibranchiata Ehlers) harvesting on survival and growth of juveniles of the soft-shell clam." J. Shellfish Res. 20(3): 1145-1157.

Bergeron N.E. \& Abrahams A.D. (1992) Estimating shear velocity and roughness length from velocity profiles. Wat. Res. Res., 28, 2155-2158.

Beukema, J. J. and J. Devlas (1989). "Tidal-current transport of thread-drifting postlarval juveniles of the bivalve Macoma balthica from the Wadden Sea to the North-Sea." Mar. Ecol. Prog. Ser. 52(2): 193-200.

Blott, S. J. and K. Pye (2001). "Gradistat: A grain size distribution and statistics package for the analysis of unconsolidated sediments." Earth Surf. Process. Landforms 26: 1237-1248.

Bourque, D., G. Miron and T. Landry (2002). "Predator-prey relationship between the nemertean Caerebratulus lacteus and the soft-shell clam, Mya arenaria: surface-exploration activity and qualitative." Can. J. Zool. 80: 1204-1211.

Bowen, J. E. and H. L. Hunt (2009). "Settlement and recruitment patterns of the soft-shell clam, Mya arenaria, on the northern shore of the Bay of Fundy, Canada." Estuaries and Coasts 32: 758-772.

Calderon, I. (ed.) (2007). Atelier de travail sur l'élevage de la mye commune. Compte rendu No 32. Les publications de la Direction de l'innovation et des technologies. Ministère de l'Agriculture, des Pêcheries et de l'Alimentation du Québec, Gaspé, 50 pp.

Chevarie, L., B. Myrand and R. Tremblay (2006). "Economical scenarios applied to soft-shell clam (Mya arenaria) culture in îles-de-la-Madeleine: Requirements for profitability." AAC Spec. Publ. 10: 61-63.

Delaporte, M., S. Synard, J. Pariseau, P. McKenna, R. Tremblay, J. Davidson and F. C. J. Berthe (2008). "Assessment of haemic neoplasia in different soft shell clam Mya arenaria populations from eastern Canada by flow cytometry." J. Inverterbr. Pathol. 98(2): 190-197.

Drapeau, G. (1988). "Stability of tidal inlet navigation channels and adjacent dredge spoil islands." In: Aubrey, D.G., Weishar, L. (Eds.), Hydrodynamics and Sediment Dynamics of Tidal Inlets. Lecture Notes on Coastal and Estuarine Studies, Springer, New York 29: 226244.

Emerson, C. W. (1991). "A Method for the measurement of bedload sediment transport and passive faunal transport on intertidal sandflats." Estuaries 14(4): 361-371.

Emerson, C. W. and J. Grant (1991). "The control of soft-shell clam (Mya arenaria) recruitment on intertidal sandflats by bedload sediment transport." Limnol. Oceanogr. 36(7): 1288-1300.

Folk, R. L. (1954). "The distinction between grain size and mineral composition in sedimentary-rock nomenclature." J. Geol. 62(4): 344-359.

Fugate, D. C. and R. J. Chant (2005). "Near-bottom shear stresses in a small, highly stratified estuary." J. Geophys. Res.-Oceans 110(C3): 13.

Gulmann, L. K., L. S. Mullineaux and H. L. Hunt (2001). "Effects of caging on retention of postlarval soft-shelled clams (Mya arenaria)." J. Shellfish Res. 20(1): 135-142. 
Guyondet, T. and V. G. Koutitonsky (2008). "Tidal and residual circulations in coupled restricted and leaky lagoons." Estuar. Coast. Shelf S. 77: 396-408.

Hendriks, I. E., L. A. Van Duren and P. J. M. Herman (2006). "Turbulence levels in a flume compared to the field: Implications for larval settlement studies." J. Sea Res. 55: 15-29.

Hunt, H. L. (2004a). "Effects of epibenthic predators on flow: transport and mortality of juveniles of the soft shell clam Mya arenaria." Mar. Ecol. Progr. Ser. 279: 151-160.

Hunt, H. L. (2004b). "Transport of juvenile clams: effects of species and sediment grain size." J. Exp. Mar. Biol. Ecol. 312: 271-284.

Hunt, H. L. (2005). "Effects of sediment source and flow regime on clam and sediment transport." Mar. Ecol. Progr. Ser. 296: 143-153.

Hunt, H. L., D. C. Fugate and R. J. Chant (2009). "Modeling bedload transport of juvenile bivalves : predicted changes in distribution and scale of postlarval dispersal." EstuariesCoastsRev: [in press].

Hunt, H. L., M.-J. Maltais, D. C. Fugate and R. J. Chant (2007). "Spatial and temporal variability in juvenile bivalve dispersal : effects of sediment transport and flow regime." Mar. Ecol. Progr. Ser. 352: 145-150.

Hunt, H. L., D. A. McLean and L. S. Mullineaux (2003). "Post-settlement alteration of spatial patterns of soft shell clam (Mya arenaria) recruits." Estuaries 26(1): 72-81.

Hunt, H. L. and L. S. Mullineaux (2002). "The Role of predation and postlarval transport in recruitment of the soft shell clam (Mya arenaria)." Limnol. Oceanogr. 47((1)): 151-164.

Jennings, L. B. and H. L. Hunt (2009). "Distances of dispersal of juvenile bivalves (Mya arenaria (Linnaeus), Mercenaria mercenaria (Linnaeus), Gemma gemma (Totten))." J. Exp. Mar. Biol. Ecol. xxx: [in press].

Jonsson, R., L. A. Van Duren, M. Amielh, R. Asmus, R. J. Aspden, D. Daunys, M. Friedrichs, P. L. Friend, F. Olivier, N. Pope, E. Precht, P. G. Sauriau and E. Schaaff (2006). "Making water flow: a comparison of the hydrodynamic characteristics of 12 different benthic biological flumes." Aquat. Ecol. 40(4): 409-438.

Koutitonsky, V. G. and G. Tita (2006). "Temps de renouvellement des eaux dans la lagune de Grande-Entrée aux Îles-de-la-Madeleine." Les publications de la Direction de I'Innovation et des Technologies - Rapport de recherche-développement 151: 1-74.

LeBlanc, S. and G. Miron (2006). "Bentho-pelagic distribution of early stages of softshell clams (Mya arenaria) in tidally contrasted regimes." Can. J. Zool. 84(3): 459-472.

Lundquist, C. J., C. A. Pilditch and V. J. Cummings (2004a). "Behaviour controls postsettlement dispersal by the juvenile bivalves Austrovenus stutchburyi and Macomona liliana." J. Exp. Mar. Biol. Ecol. 306(1): 51-74.

Lundquist, C. J., S. F. Thrush, J. E. Hewitt, J. Halliday, L. MacDonald and V. J. Cummings (2006). "Spatial variability in recolonisation potential: influence of organism behaviour and hydrodynamics on the distribution of macrofaunal colonists." Mar. Ecol.-Prog. Ser. 324: 6781.

Lundquist, C. J., S. F. Thrush, J. W. Oldman and A. K. Senior (2004b). "Limited transport and recolinization potential in shallow tidal estuaries." Limnol. Oceanogr. 49(2): 386-395.

Matthiessen, G. C. (1960). "Intertidal zonation in populations of Mya arenaria." Limonolygy and Oceanography 5(4): 381-388.

McGladdery, S., C. Reinisch, G. S. MacCallum, R. E. Stephens, C. L. Walker and J. T. Davidson (2001). "Haemic neoplasia in soft-shell clams (Mya arenaria): recent outbreaks in Atlantic Canda and discovery of a p53 gene homologue associated with the condition." Bull. Aquacul. Assoc. Canada 101(3): 19-26.

McManus, J. (1988). "Grain size determination and interpretation." In : Tucker M. (ed) Techniques in Sedimentology. Blackwell Scientific Publication: pp. 63-85.

Miron, G., D. Audet, T. Landry and M. Moriyasu (2005). "Predation potential of the invasive green crab (Carcinus maenas) and other common predators on commercial bivalve species found on Prince Edward island." J. Shellfish Res. 24(2): 579-586.

Muschenheim, D. K., J. Grant and E. L. Mills (1986). "Flumes for benthic ecologists: theory, construction and practice." Mar. Ecol. Progr. Ser. 28: 185-196. 
Norkko, A., V. J. Cummings, S. F. Thrush, J. E. Hewitt and T. Hume (2001). "Local dispersal of juvenile bivalves : implications for sandflat ecology." Mar. Ecol. Progr. Ser. 212: 131-144.

Nowell, A. R. M. and P. A. Jumars (1984). "Flow environments of aquatic benthos." Ann. Rev. Ecol. Syst. 15: 303-328.

Olivier, F. (1997). "Régulation des populations de recrues en régime mégatidal: effet du couplage physique-biologique en couche limite benthique." Université de Rennes 1, Rennes: $135 \mathrm{p}$.

Olivier, F., N. Desroy and C. Retiere (1996). "Habitat selection and adult-recruit interactions in Pectinaria koreni (Malmgren) (Annelida: Polychaeta) post-larval populations: Results of flume experiments." J. Sea Res. 36(3-4): 217-226.

Olivier, F. and C. Retiere (1998). "The role of physical-biological coupling in the benthic boundary layer under megatidal conditions: The case of the dominant species of the Abra alba community in the eastern Baie de Seine (English channel)." Estuaries 21(4A): 571-584.

Pariseau, J., B. Myrand, G. Desrosiers, L. Chevarie and M. Giguere (2007). "Influences of physical and biological variables on softshell clam (Mya arenaria Linneaus 1758) burial." J. Shellfish Res. 26(2): 391-400.

Pernet, F., R. Tremblay and E. Bourget (2003). "Settlement success, spatial pattern and behavior of mussel larvae Mytilus spp. in experimental "down-welling" systems of varying velocity and turbulence." Mar. Ecol. Progr. Ser. 260: 125-140.

Pethua, E. T., C. J. Lundquist and C. A. Pilditch (2006). "Estimating spatial scale of postsettlement transport potential of Macomona liliana on an intertidal sandflat." New Zeal. J. Mar. Fresh. 40: 487-502.

Pope, N. D., J. Widdows and M. D. Brinsley (2006). "Estimation of bed shear stress using the turbulent kinetic energy approach - A comparison of annular and field data." Cont. Shelf Res. 26: 959-970.

Roegner, C., C. André, M. Lindegarth, J. E. Eckman and J. Grant (1995). "Transport of recently settled soft-shell clams (Mya arenaria L.) in laboratory flume flow." J. Exp. Mar. Biol. Ecol. 187: 13-26.

Sobral, P. and J. Widdows (2000). "Effects of increasing current velocity, turbidity and particle-size selection on the feeding activity and scope for growth of Ruditapes decussatus from Ria Formosa, southern Portugal." J. Exp. Mar. Biol. Ecol. 245: 111-125.

Sousa, W. P. (1993). "Size-dependant predation on the salt-marsh snail Cerithidea californica Haldeman." J. Exp. Mar. Biol. Ecol. 166(1): 19-37.

St-Onge, P. and G. Miron (2007). "Effects of current speed, shell length and type of sediment on the erosion and transport of juvenile softshell clams (Mya arenaria)." J. Exp. Mar. Biol. Ecol. 349(1): 12-26.

St-Onge, P., G. Miron and G. Moreau (2007). "Burrowing behaviour of the softshell clam (Mya arenaria) following erosion and transport." J. Exp. Mar. Biol. Ecol. 340: 103-111.

Vogel, S. (1994). "Life in moving fluids: The physical biology of flow." Princeton University Press, Princeton, NJ 2nd ed.: 467 p.

Volkenborn, N., D. M. Robertson and K. Reise (2009). "Sediment destabilizing and stabilizing bio-engineers on tidal flats: cascading effects of experimental exclusion." Helgol Mar Res 63: 27-35.

Widdows, J. and M. Brinsley (2002). "Impact of biotic and abiotic processes on sediment dynamics and the consequences to the structure and functioning of the intertidal zone." $\mathrm{J}$. Sea Res. 48(2): 143-156.

Zaklan, S. D. and R. Ydenberg (1997). "The body size burial depth relationship in the infaunal clam Mya arenaria." J. Exp. Mar. Biol. Ecol. 215(1): 1-17. 
Flume top view

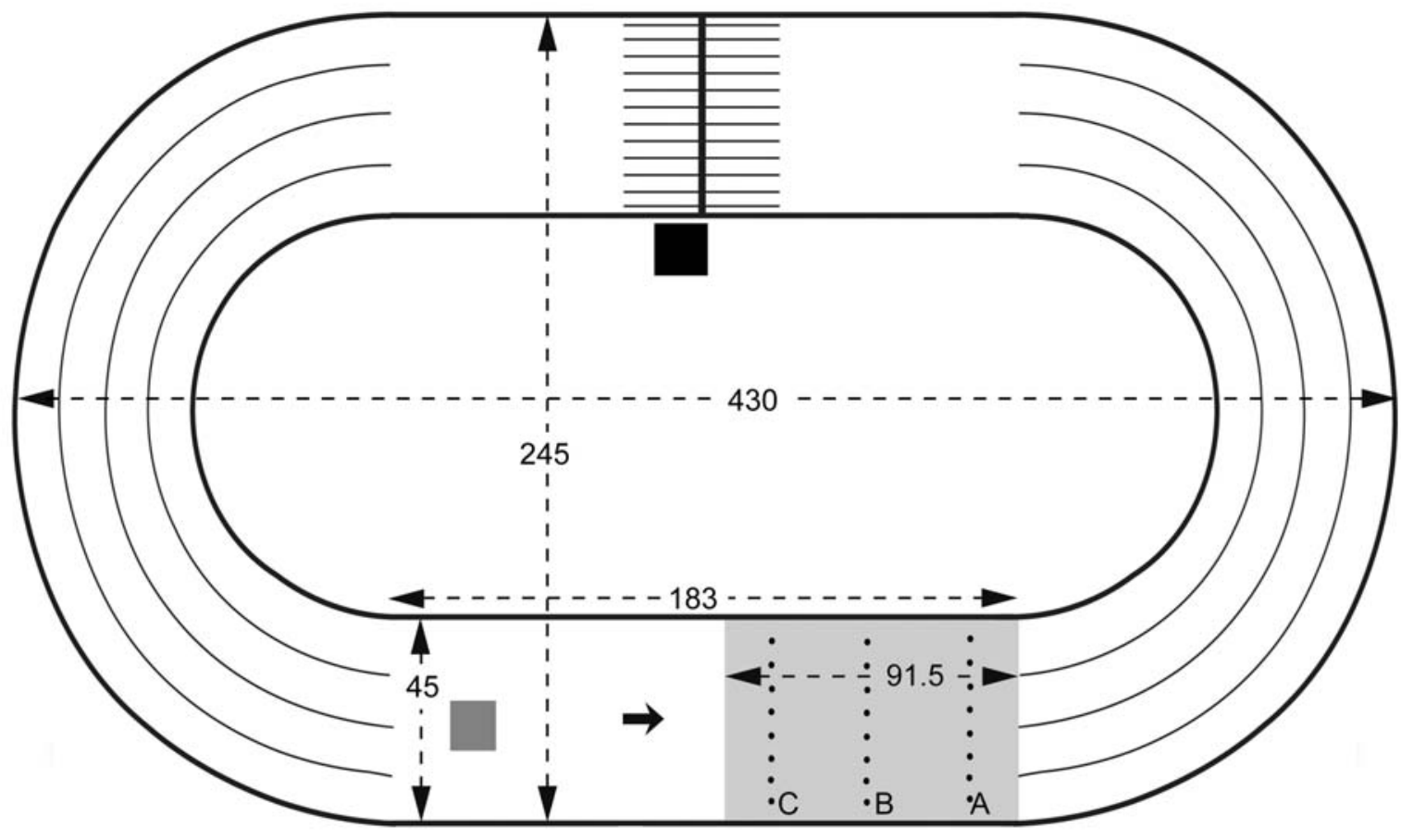

Experimentation area $\square 1 \mathrm{hp}$ engine $\quad$ TKE generator device

$\rightarrow$ Current direction $\quad \cdot$ Current measurement coordinates

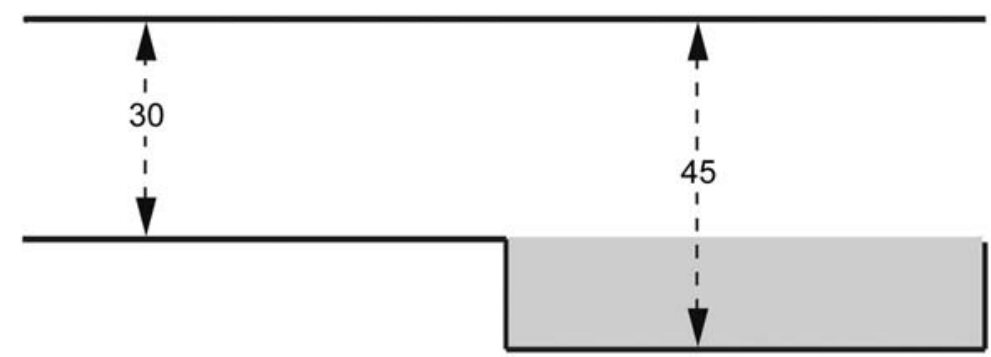

Flume side view

Figure 1. Schematic drawing of the benthic biological flume Aquatron, with positions of flowmeasurement transects A, B (also clam position line), and C. Dimensions are in $\mathrm{cm}$. 


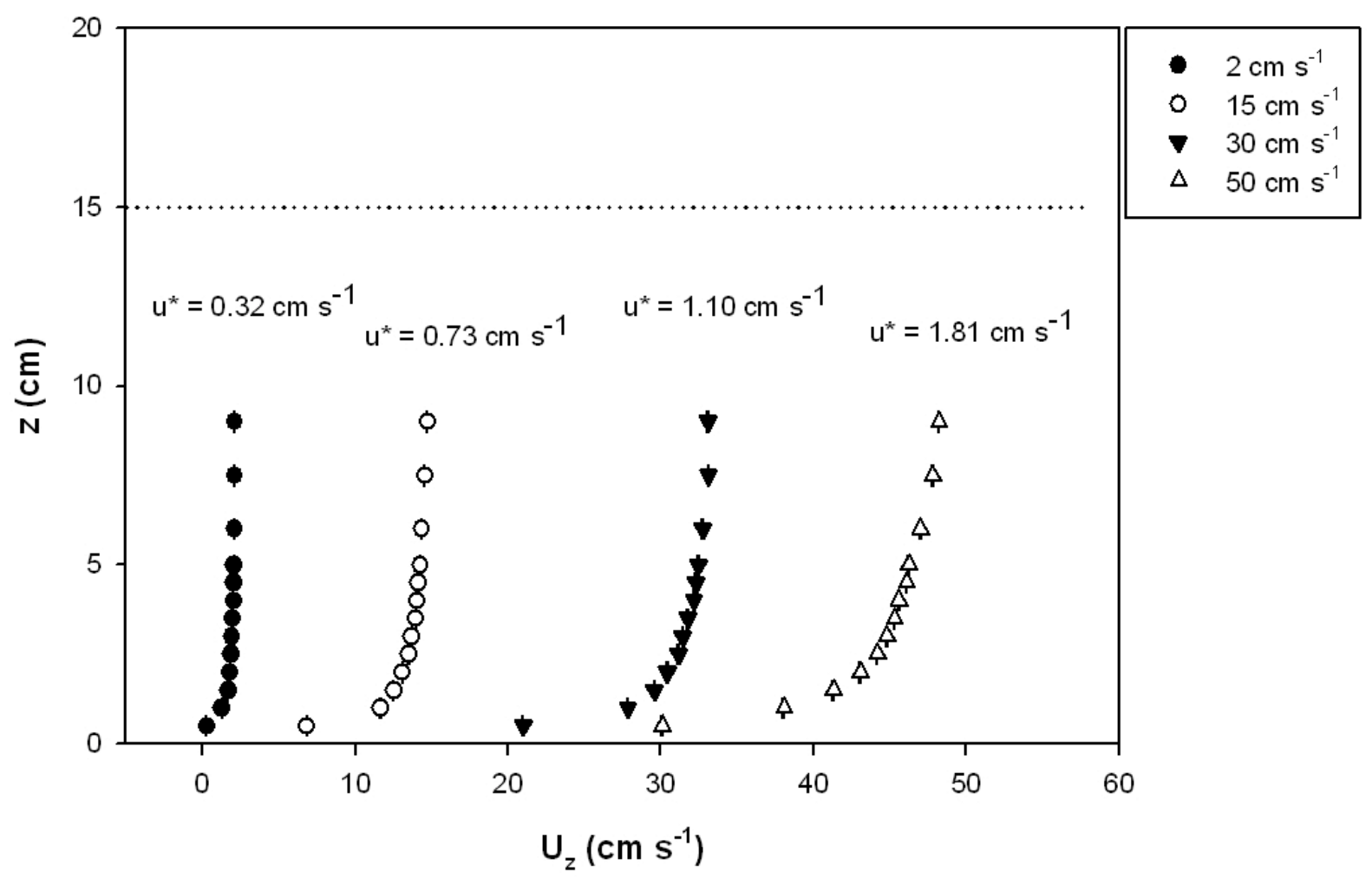

Figure 2. Vertical profiles for increasing velocities $\left(U_{\infty}\right)$ (mean $\pm S D$ ) in the benthic flume at different height $(z)$ values. The horizontal dotted line indicates the water level in the flume (15 $\mathrm{cm})$.

\section{internal side}

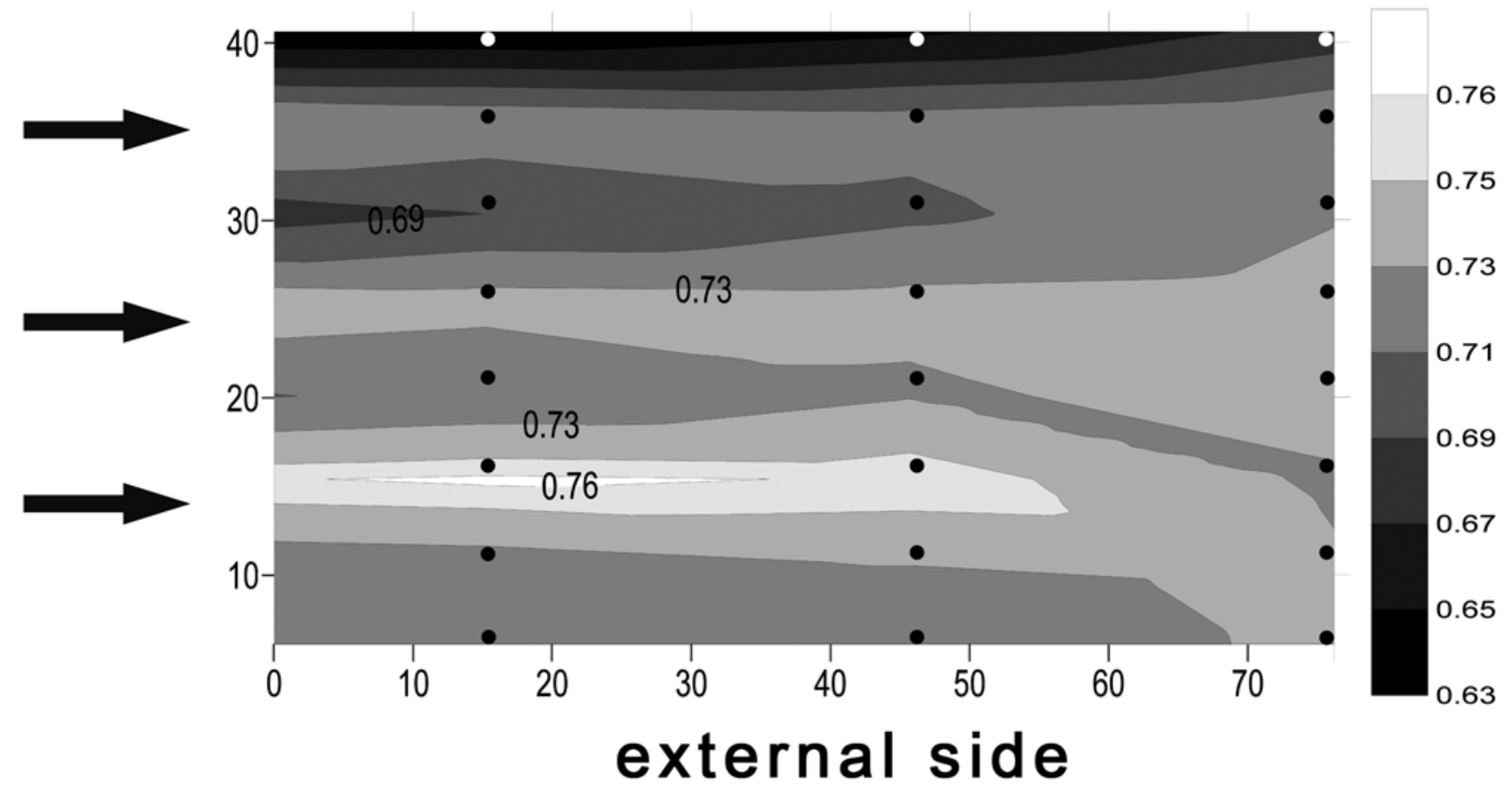


Figure 3. Horizontal variations of $u_{*}\left(\mathrm{~cm} \mathrm{~s}^{-1}\right)$ across the experimental zone for a $15 \mathrm{~cm} \mathrm{~s}$ free stream velocity (dimensions are given in $\mathrm{cm}$ ).

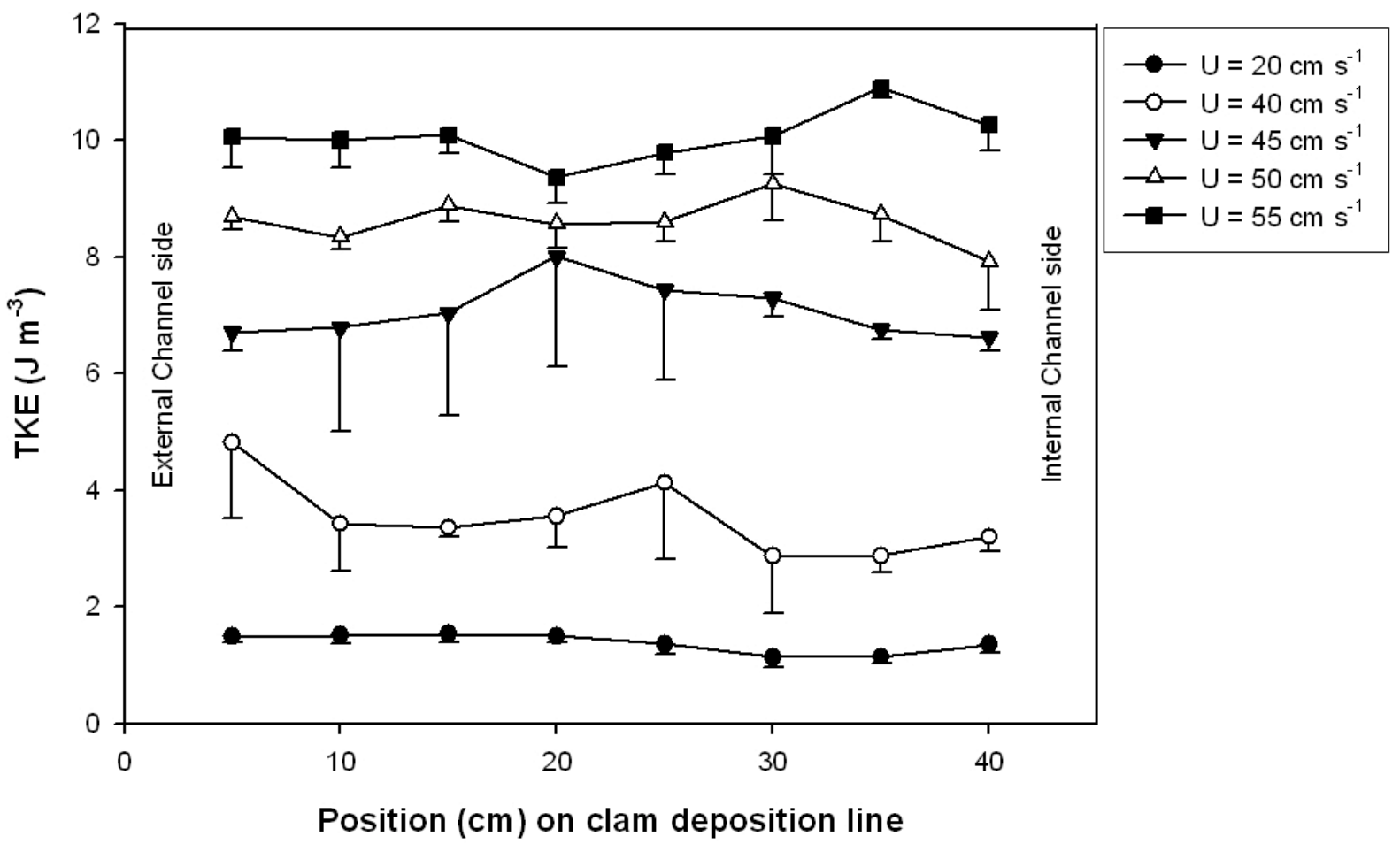

Figure 4. Turbulent kinetic energy (TKE) (mean $\pm \mathrm{SD}$ ) during the wave-current experiments measured along the clam position line across the channel (B in Fig. 1), five current steps with constant wave-generator frequency of 120 CPM. 
Textural classes

gS : Gravelly sand

(g)S : Slighlty gravelly sand mgS : Muddy gravelly sand msG : Muddy sandy gravel S: $\quad$ Sand

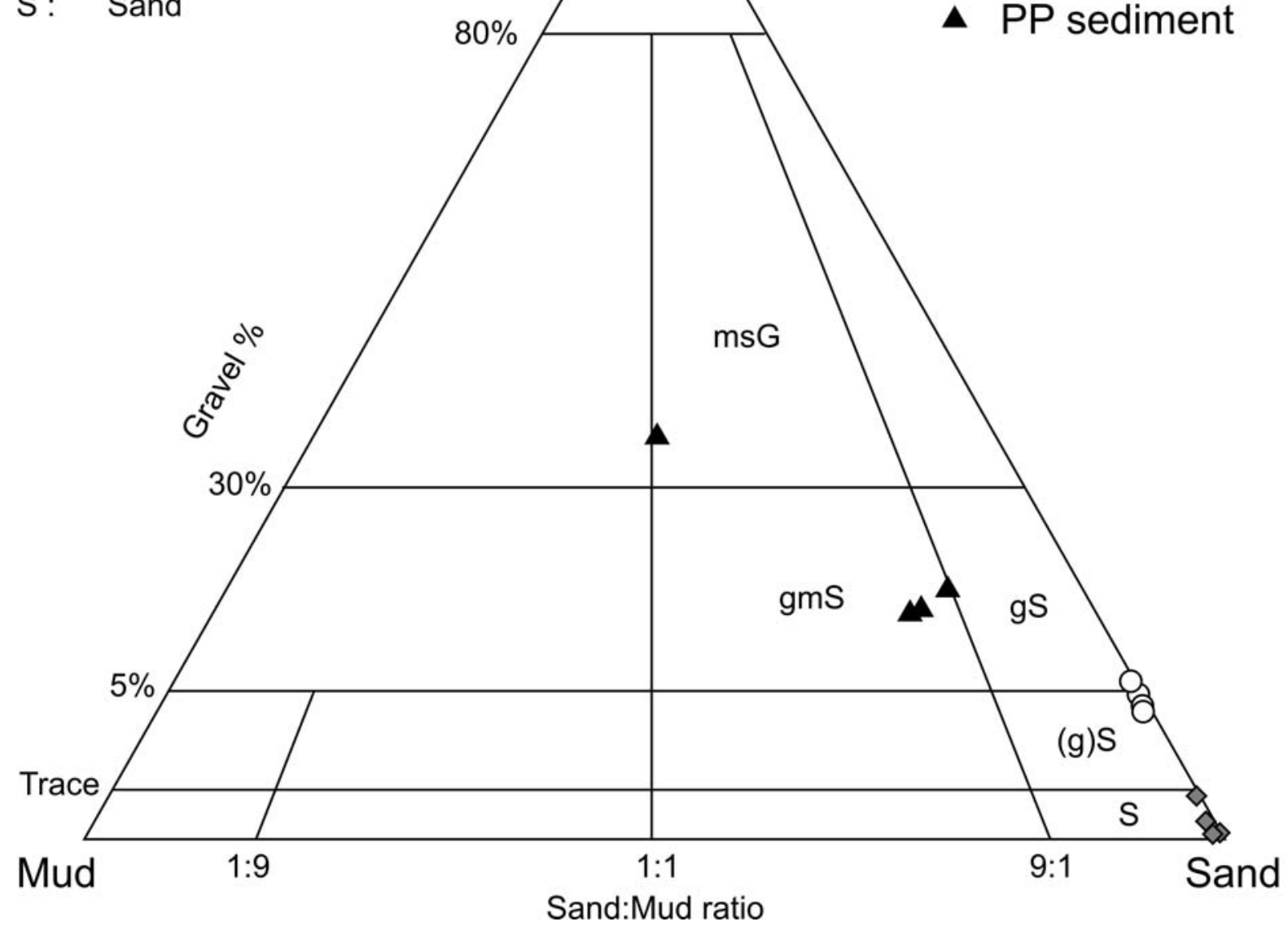

Figure 5. Grain size analyses of the three experimental substrates presented in the ternary gravel-sand-mud diagram with textural classes according to Folk (1954). 

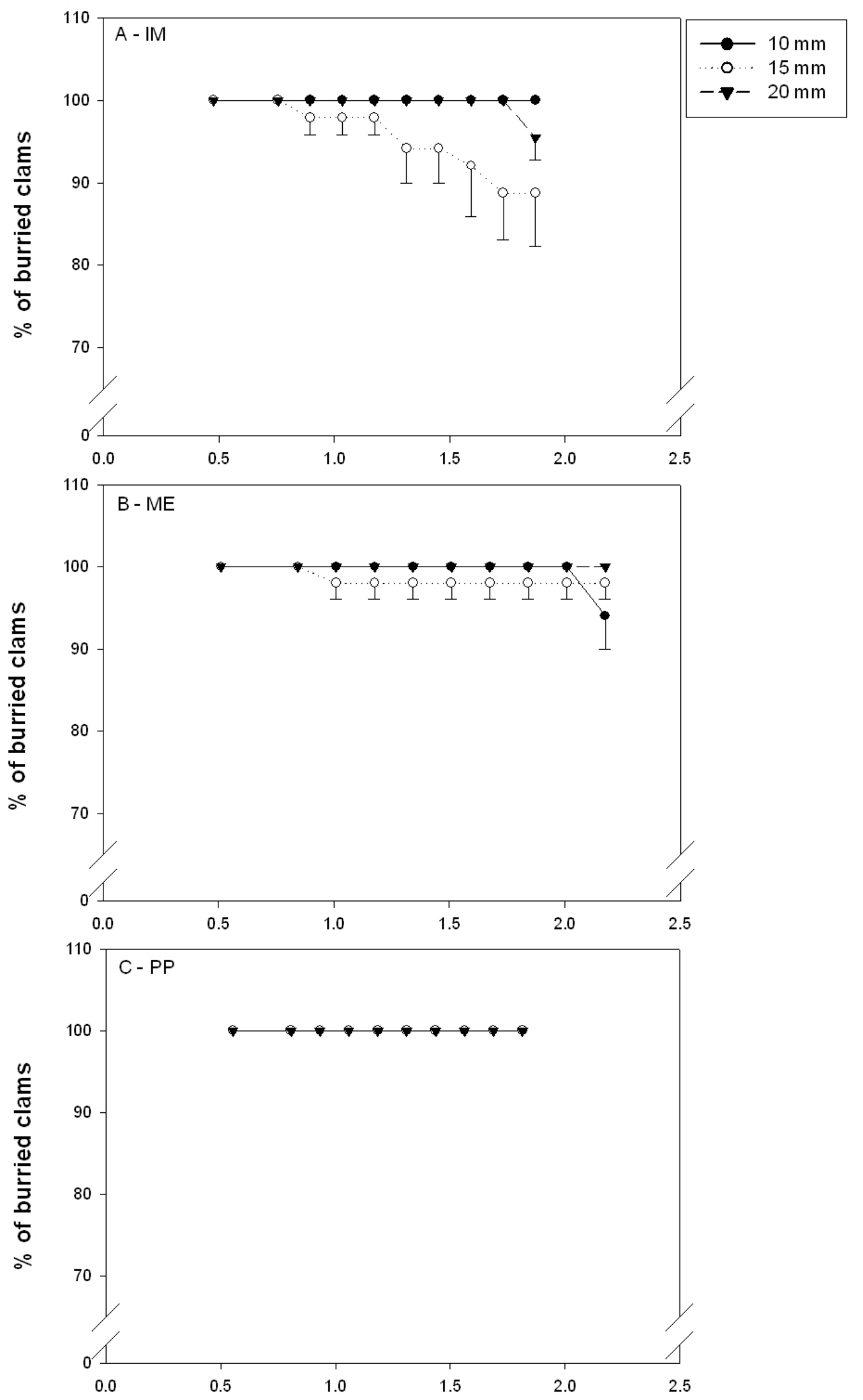

$$
\mathrm{u}^{*}\left(\mathrm{~cm} \mathrm{~s}^{-1}\right)
$$

Figure 6. Percentage of buried clams (mean $\pm \mathrm{SD}$ ) for the three length classes in different substrates after exposition to unidirectional currents of different velocities in the experimental 
benthic flume: a) medium sand from Îles-de-la-Madeleine (IM), b) coarse sand from Métis (ME), c) muddy sand from Pointe-au-Père (PP).

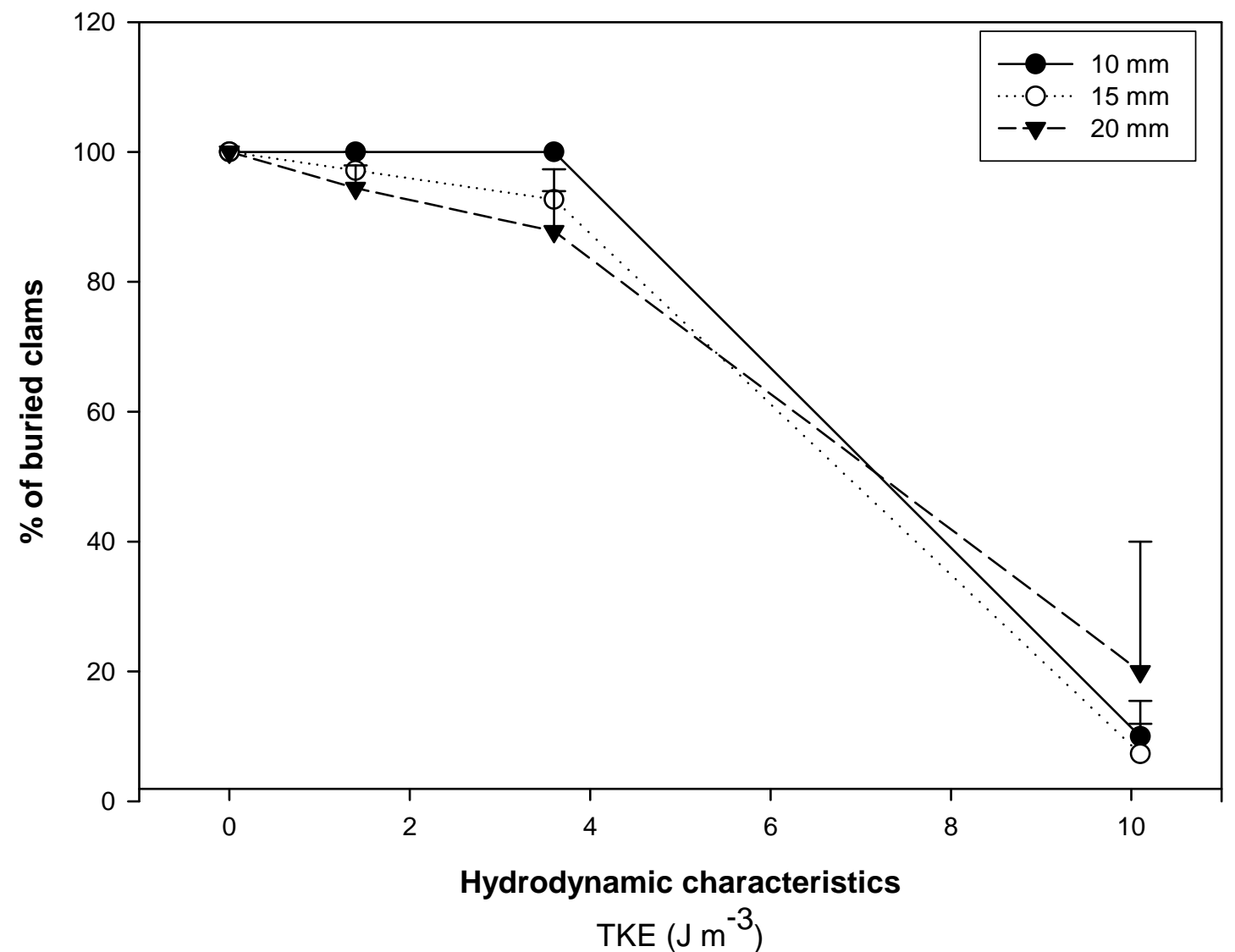

Figure 7. Percentage of buried clams (mean $\pm \mathrm{SD}$ ) in medium sand (IM) when exposed to wave generator action (120 CPM) with an increasing current velocity ( $\left.\mathrm{cm} \mathrm{s}^{-1}\right)$ in the experimental benthic flume. 


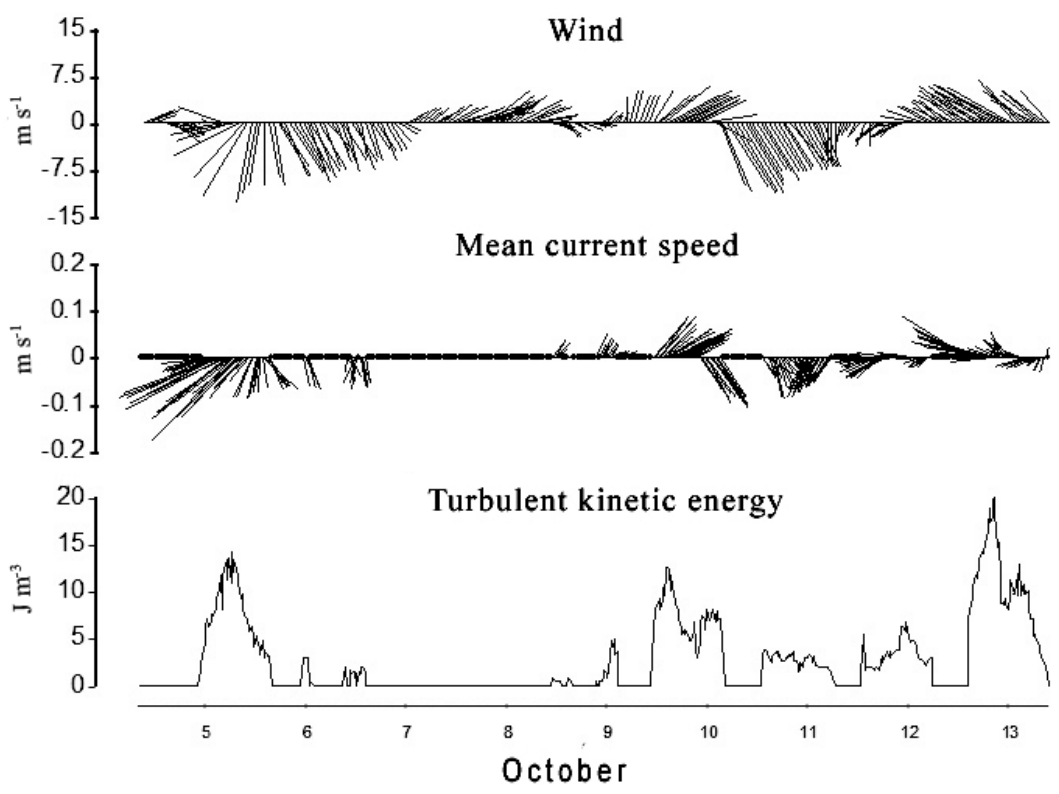

Figure 8. Environmental conditions measured at the Havre-aux-Maisons field site from 5 to 14 October 2006.
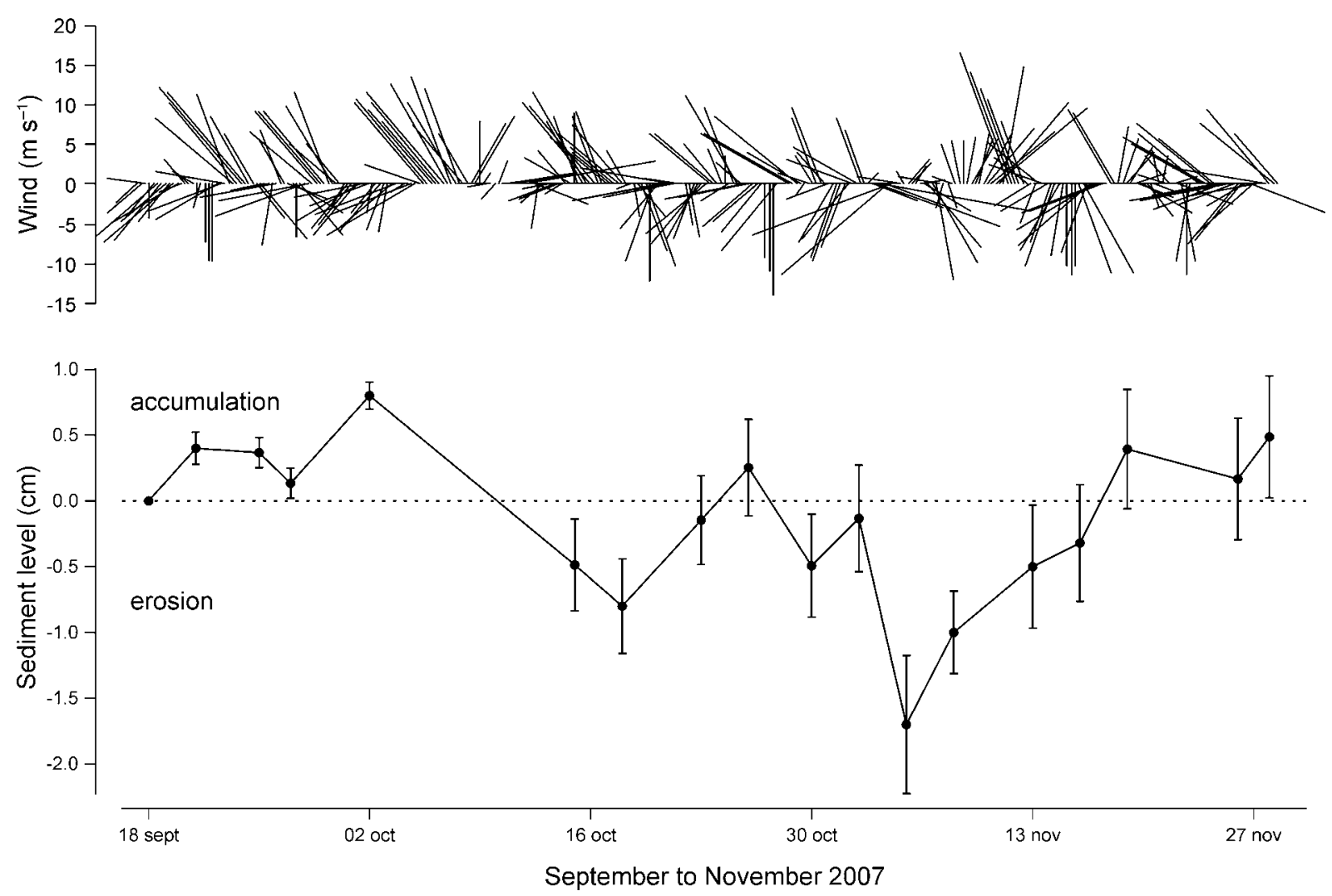

Figure 9. Changes in bed levels (mean \pm SD) measured at the Havre-aux-Maisons field site from September to November 2007. 


\begin{tabular}{|c|c|c|c|c|c|}
\hline Free stream Velocity $\left(\mathrm{cm} \mathrm{s}^{-1}\right)$ & & 15 & 30 & 45 & 60 \\
\hline \multicolumn{6}{|l|}{ Mean $\mathrm{U}^{*} \pm \mathrm{SD}\left(\mathrm{cm} \mathrm{s}^{-1}\right)$} \\
\hline & IM & $0.44 \pm 0.05$ & $1.25 \pm 0.13$ & $1.55 \pm 0.22$ & $1.73 \pm 0.44$ \\
\hline & ME & $0.59 \pm 0.06$ & $1.28 \pm 0.08$ & $1.73 \pm 0.16$ & $2.10 \pm 0.33$ \\
\hline & PP & $0.56 \pm 0.10$ & $1.20 \pm 0.15$ & $1.51 \pm 0.31$ & $1.72 \pm 0.41$ \\
\hline \multicolumn{6}{|l|}{$\overline{\operatorname{Re}}$} \\
\hline & IM & 10343.75 & 29483.33 & 36596.35 & 40808.85 \\
\hline & ME & 13340.63 & 28942.19 & 39245.31 & 47589.58 \\
\hline & PP & 9052.60 & 19389.58 & 24445.83 & 27723.96 \\
\hline \multicolumn{6}{|l|}{$\overline{R^{*}}{ }^{*}$} \\
\hline & IM & 1.17 & 3.33 & 4.13 & 4.61 \\
\hline & ME & 2.12 & 4.59 & 6.22 & 7.55 \\
\hline & PP & 15.90 & 34.05 & 42.93 & 48.69 \\
\hline \multicolumn{6}{|l|}{ Mean TKE \pm SD $\left(\mathrm{J} \mathrm{m}^{-3}\right)$} \\
\hline & IM & $0.14 \pm 0.11$ & $0.63 \pm 0.35$ & $0.89 \pm 0.61$ & $1.78 \pm 1.09$ \\
\hline & ME & $0.14 \pm 0.02$ & $0.56 \pm 0.09$ & $0.99 \pm 0.15$ & $1.13 \pm 0.89$ \\
\hline & PP & $0.07 \pm 0.05$ & $0.15 \pm 0.15$ & $0.24 \pm 0.19$ & $0.28 \pm 0.24$ \\
\hline
\end{tabular}

Table 1. Hydrodynamic characteristics (mean \pm SD) above three different sediments (Medium sand - IM, coarse sand - ME and muddy sand - PP). Re is measured for a $15 \mathrm{~cm}$ water column. 